\title{
Motorcycle accidents in tropical environments: injury mechanisms and anatomo-clinical aspects
}

\begin{abstract}
Background: To describe the mechanisms of injury and the anatomo-clinical aspects of trauma caused by motorized two-wheeled vehicles at the Bouaké University Hospital,

Methods: This was a retrospective descriptive study performed in the surgical emergency department of the Bouaké University Hospital. It lasted for a period of 08 months from February 1, 2015 to September 30, 2015. It concerned patients admitted to surgical emergencies for injuries that occurred during an accident involving a motorcycle. Neglected trauma due to accidents involving motorcycles, accident victims not involving motorcycles were not included in our study. The data collected were: age, sex, occupation, circumstances and mechanism of the accident, seat of the lesion and injury report.
\end{abstract}

Results: During this study period, 2,647 emergency room patients were registered with 615 injuries due to motorcycle accidents. The frequency of road accidents caused by motorized two-wheelers accounted for $23.23 \%$ of surgical emergency room admissions. The average age of the victims was $31.9 \pm 16.7$ years with extremes of 1 day and 95 years. There were 468 men $(76.09 \%)$ and 147 women $(23.91 \%)$, and the 21-30 age group was the most representative with $(\mathrm{n}=195,31.70 \%)$ case. Students were the most affected $(n=270,43.91 \%)$ on traders $(n=142,23.09 \%)$. Motorcycle drivers $(n=304,49.44 \%)$ and motorcycle rear passengers $(n=175,28.45 \%)$ were the most affected. The most common types of accidents were motorcycle versus car $(\mathrm{n}=174,28.29 \%)$, motorcycle versus pedestrian $(\mathrm{n}=154,25.05 \%)$, and mishandled motorcycles $(\mathrm{n}=174 ; 143,23.25 \%)$ of the cases. The majority of patients did not wear safety helmets $(\mathrm{n}=492,80 \%)$. The lesions observed during our study sat preferentially at the limb level $(\mathrm{n}=344,55.93 \%)$ and Skull $\mathrm{n}=115 ; 18.7 \%)$. Soft-tissue wounds $(\mathrm{n}=247,40.15)$ predominated the cases, followed by fractures $(\mathrm{n}=145,23.57 \%)$. There were eleven deaths $(\mathrm{n}=11,1.79 \%)$.

Conclusion: Road accidents due to two-wheeled vehicles (motorcycles) are more and more frequent in Bouaké. Motorcycle-to-car accidents are common. Deaths were due to head trauma in the majority of cases. Compliance with the Highway Code and mandatory use of a safety helmet could reduce the number and severity of injuries.
Volume 2 Issue I - 2018

Kouassi Kouamé Jean Eric, M’bra Kouame
Inocent, Yao Loukou Blaise, Sery Bada Justin
Leopold Niaore, Krah Koffi Leopold, Michel
Kodo
Department of Trauma and Orthopaedics, University of Alassane Ouattara, Côte d'Ivoire

Correspondence: Kouassi Kouame Jean Eric, Department of Trauma and Orthopaedics, Bouaké Teaching Hospital, University of Alassane Ouattara, Côte d'lvoire, Tel +22507899242, Email medericko@yahoo.fr

Received: January 10, 2018 | Published: January 19, 2018

Keywords: accident, injury, mechanism, public roads, motorcycles

\section{Introduction}

Road accidents remain a serious public health problem at the global, regional and national levels. While action is being taken in many countries to improve road safety, much remains to be done if we want the number of deaths to stop increasing. ${ }^{1}$ The African region still has one of the highest traffic fatality rates. More than $90 \%$ of road deaths occur in low- and middle-income countries, where only $48 \%$ of the world's population is found. ${ }^{2}$ The advent of new, more powerful and financially accessible motorized two-wheelers is accentuating the problem in Africa. Road accidents involving motorcycles are part of the day-to-day operations of the University Hospital of Bouaké. The purpose of this study was to describe the lesional mechanisms and anatomy-clinical aspects of motorcycle accident injuries.

\section{Methods}

This was a descriptive, retrospective study performed in the surgical emergency departments of the Bouaké University Hospital. It lasted for a period of 08 months from February 1, 2015 to September
30, 2015. It concerned patients admitted to surgical emergencies for injuries that occurred during a motorcycle accident involving a motorcycle. Neglected trauma due to accidents involving motorcycles, accident victims not involving motorcycles, was not included in our study. The data collected were: age, sex, occupation, circumstances and mechanism of the accident, the seat of the lesion and the injury report.

\section{Results}

During this study period, 2,647 patients admitted to the emergency department were registered with 615 injuries due to accidents involving motorcycles. The frequency of road accidents caused by motorized two-wheelers accounted for $23.23 \%$ of surgical emergency room admissions. The average age of the victims was $31.9 \pm 16.7$ years with extremes of 1 day and 95 years. There were 468 males $(76.09 \%)$ and 147 females (23.91\%), and the 21-30 age group was the most representative with a strength of $(n=195,31.70 \%)$ (Figure 1). The circumstances of occurrence of motorcycle accidents are listed in Table 1 . The type of user is listed in Table 2 . The majority of patients 
did not wear safety helmets ( $\mathrm{n}=390,79.75 \%)$. The lesions observed during our study sat preferentially at the limb level (Table 3). Injuries of upper extremity limbs in $(\mathrm{n}=211 ; 34.30 \%)$ cases and lower limb in $(\mathrm{n}=133 ; 21.63 \%)$. The soft-tissue wounds predominated with $(n=247,40.15 \%)$, followed by fractures $(n=145,23.57 \%)$, and muscle contusions ( $\mathrm{n}=137,22.27 \%$ ) (Table 4) Eleven (1.79\%) patients died in the emergency department. The causes were: severe head injury $(n=7)$, severe contusion of the abdomen $(n=2)$ and two polytrauma patients $(\mathrm{n}=2)$.

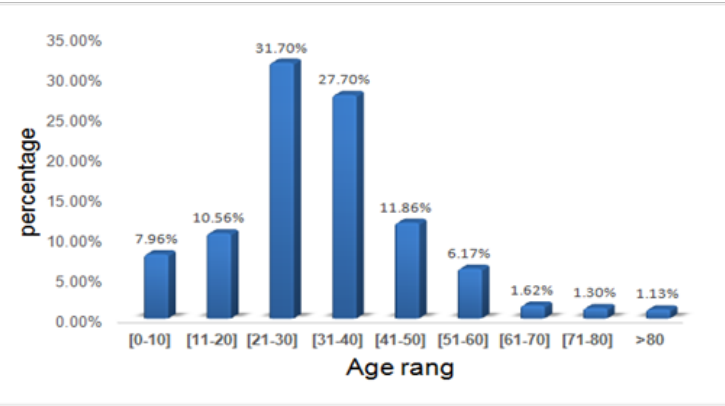

Figure I Distribution by age group.

Table I Distribution of Mechanisms by Patient

\begin{tabular}{lll}
\hline Type of accident & N & $\%$ \\
\hline Motorcycle against Car & 174 & 28,29 \\
Motorcycle against Pedestrian & 154 & 25,05 \\
False maneuver & 143 & 23,25 \\
Motorcycle against Motorcycle & 118 & 19,18 \\
Accident Wheel spokes & 11 & 1,78 \\
Motorcycle against Bicycle & 10 & 1,63 \\
Motorcycle against animal & 5 & 0,82 \\
Total & 615 & 100
\end{tabular}

Table 2 The distribution of the type of user according to the patients

\begin{tabular}{lll}
\hline Type of users & N & $\%$ \\
\hline Motorcycle Driver & 304 & 62,16 \\
Motorcycle rear passenger & 175 & 35,79 \\
Cyclists & 10 & 2,05 \\
Total & 489 & 100 \\
\hline
\end{tabular}

Table 3 Distribution of lesions by seat of the lesion

\begin{tabular}{lll}
\hline Topography & N & $\%$ \\
\hline Member & 344 & 55,93 \\
Crane & 115 & 18,7 \\
Maxillo-facial/ O.R.L & 84 & 13,7 \\
Basin & 26 & 4,21 \\
Abdomen & 16 & 2,60 \\
Spine & 15 & 2,43 \\
Thorax & 15 & 2,43 \\
Total & 615 & 100 \\
\hline
\end{tabular}

Table 4 Distribution by type of lesions

\begin{tabular}{lll}
\hline Lesions & N & $\%$ \\
\hline Wound of soft parts & 247 & 40,16 \\
Fractures & 145 & 23,57 \\
Muscular contusion & 137 & 22,27 \\
Sprain & 41 & 6,67 \\
Dislocation & 33 & 5,37 \\
Durical & 12 & 1,96 \\
hematomas & 615 & 100 \\
\hline
\end{tabular}

\section{Discussion}

Motorcycle accidents are a public health problem. ${ }^{1}$ They represent $23.23 \%$ of the cases in our study. These accidents are constantly increasing in our regions because of the proliferation of high-speed machines. The most common lesion mechanism in our study was motorcycle-to-car collision. This mechanism of injury is reported in the literature..$^{3-5}$ There are several reasons for this: the lack of mastery of these multi-speed machines that require a driver's license; ignorance of the Highway Code, the lack of knowledge of safety measures including the non-overload and speed limitation, the virtual absence of road signs, the motorcycle is used for commercial purposes (motorcycle taxi) and the degradation of the way public. ${ }^{4-6}$ The young male population is the victims of most motorcycle accidents. ${ }^{5-7}$ This segment of the population is the most mobile and active. ${ }^{3}$ Lesions predominate in the limbs. This has been reported in the literature. ${ }^{8,9}$ This is due to the lack of cockpit that can protect motorcycle users. ${ }^{9}$

The fall of a motorized two-wheeled machine can cause a slip that causes wounds and burns by friction, and end with a shock against an obstacle (sidewalk, vehicle, and guardrail) that will cause secondary traumatic injuries. This explains the large number of mucocutaneous lesions in our patients who were not wearing protective clothing most often. ${ }^{9}$ In motorcycle accidents, the most common injuries are those of the soft parts followed by fractures..$^{10}$ But the lesions of the trunk (chest and abdomen) and the head are the most serious. Indeed, in our study, all the deceased patients had lesions of these different parts of the body. In traumas of the thorax, the lesions are made by compression. They sit next to the point impact on the parietal level and directly underlying structures. ${ }^{11}$ Kinetic energy at the time of injury is the main determinant of lesion severity. ${ }^{11}$ Intra-abdominal organ damage is done by crushing or splitting. It is essentially perforation of the digestive tract, bursting of solid organs, mesenteric lacerations by direct hyper pressure or vascular lesions. The severity of the intraabdominal lesions increases with the energy of the trauma. ${ }^{12}$

The projection of the patient on the ground can lead to cranioencephalic traumas whose severity depends on the speed of projection of the casualty on the ground and wearing or not wearing a helmet. In our study, $20.25 \%$ of patients wore a helmet. Helmets are not commonly used in developing countries. ${ }^{6}$ Most of the deaths in our study are due to unprotected head trauma. ${ }^{13-15}$ Brain trauma can also occur as a result of sudden deceleration. Each mechanism causes different types of injuries ranging from concussion to lethal head trauma. Wearing a helmet must be mandatory for both the driver and the motorcycle passengers. Motorcycle accidents also cause high-level trauma energy and constitute situations at risk of pelvic fracture ${ }^{16}$ as was the case in ours. 


\section{Conclusion}

Road accidents due to two-wheeled vehicles (motorcycles) are more and more frequent in Bouaké. Motorcycle-to-car accidents are common. The young active population is the most concerned. The members were the most affected. Deaths were due to head trauma in the majority of cases. Compliance with the Highway Code and mandatory use of a safety helmet could reduce the number and severity of injuries.

\section{Acknowledgements}

None.

\section{Conflict of interest}

The author declares no conflict of interest.

\section{References}

1. Rapport de situation sur la sécurité routière dans le monde. il est temps d'agir. Genève, Organisation mondiale de la Santé, Switzerland; 2006. p. $1-55$.

2. Rapport de situation sur la sécurité routière dans le monde. Genève, Organisation mondiale de la Santé. Switzerland; 2015. p. 1-16.

3. Chalya PL, Mabula JB, Ngayomela IH, et al. Motorcycle injuries as an emerging public health problem in Mwanza City, north-western Tanzania. Tanzan J Health Res. 2010;12(4):214-221.

4. Solagberu BA, Ofoegbu CKP, Nasir AA, et al. Motorcycle injuries in a developing country and the vulnerability of riders, passengers, and pedestrians. Inj Prev. 2006;12(4):266-268.

5. Oluwadiya KS, Olasinde LM, Fadiora AA. Motorcycle limb injuries in a developing country. WAJM. 2004;23(1):42-47.
6. Nwadiaro HC, Ekwe KK, Akpayack IC, et al. Motorcycle injuries in north-central Nigeria. Niger J Clin Pract. 2011;14(2):186-189.

7. Vieira Rde C, Hora EC, de Oliveira DV, et al. An epidemiological survey on motorcycle accident victims assisted at a reference trauma center of Sergipe. Rev Esc Enferm USP. 2011;45(6):1359-1363.

8. Makoutode M, Capo Chichio B, Tsafak JP, et al. Fréquence des accidents de la voie publique chez les conducteurs de taxi-motos de 1997 à 2000 dans la ville de Cotonou au Bénin. Le Bénin Médical. 2001;19:43-47.

9. Bousso A, Camara EHS, Sané JC, et al. Aspects épidémiologique et clinique des accidents de scooter à Dakar, Sénégal. Med Afr Noire. 2011;58(4):165-168

10. Allode SA, Mensah E, Tchaou B, et al. Les urgences traumatologiques par accident sur la voie publique dans le Service de Chirurgie Générale du CHOU de Parakou (Bénin). Rev CAMES. 2008;2(6):49-52.

11. Muller L, Lefrant JY, de La Coussaye JE. Traumatismes fermés du thorax. Conférences d'actualisation, Brazil; 2005. p. 239-260.

12. Muller Laurent, Bénézet Jean François, de La Coussaye Jean Emmanuel, et al. Contusions abdominales graves :stratégie diagnostique et thérapeutique. EMC Anesthésie-Réanimation. 2003;[36-725-C-10]:1 p.

13. Santos AM, Moura ME, Nunes BM, et al. Profile of motorcycle accident victims treated at a public hospital emergency department. Cad Saude Publica. 2008;24(8):1927-1938.

14. Alicioğlu B, Yalniz E, Eşkin D, et al. Injuries associated with motorcycle accidents. Acta Orthop Traumatol Turc. 2008;42(2):106-111.

15. Khanbhai M, Lutomia MBL. Motorcycle Accident injuries seen at Kakamega Provincial Hospital in Kenya. Afr J surg. 1990;17(1):1-4.

16. Elyazid M, Raffaele G, Nicolas T, et al. Traumatisme du bassin. Rev Med Suisse. 2008;4:2723-2730. 